\title{
Identifying a novel powdery mildew resistance gene in a barley landrace from Morocco
}

\author{
Urszula Piechota $^{1}$ (D) Paweł C. Czembor ${ }^{1}$ • Piotr Słowacki ${ }^{1}$ • Jerzy H. Czembor ${ }^{1}$ \\ Received: 19 February 2019 / Revised: 25 June 2019 / Accepted: 4 July 2019 / Published online: 17 July 2019 \\ (C) The Author(s) 2019
}

\begin{abstract}
Powdery mildew is a barley foliar disease that causes great loss in yield. Because of the limited number of effective resistance genes, efforts to identify new sources of resistance are frequently focused on genetically diversified landraces. The goal of this study was to characterise the powdery mildew resistance gene in barley line 2553-3 selected from the Moroccan landrace. Phytopathological testing against a set of differential pathogen isolates revealed different pattern responses of this gene from those of other known resistance genes. $F_{2}$ and $F_{2: 3}$ (2553-3 $\times$ Manchuria) mapping populations were employed to investigate resistance inheritance. Two approaches were applied for the linkage analysis: in the first approach, 22 resistant and 21 susceptible homozygous $\mathrm{F}_{2}$ plants genotyped by the DArTseq platform (Diversity Arrays Technology, Pty. Ltd.) were used; in the second, 94 $\mathrm{F}_{2}$ plants were genotyped by converted DArTseq markers and SSRs. Both analyses delineated a new resistance gene on the short arm of chromosome $2 \mathrm{H}$. The authors propose MlMor as a gene symbol for newly characterized powdery mildew resistance genes in barley line 255-3-3. The results presented herein provide a good foundation for the development of closer linkage markers and MAS breeding.
\end{abstract}

Keywords Barley (Hordeum vulgare L.) · DArTseq markers · Powdery mildew (Blumeria graminis f. sp. hordei) $\cdot$ Resistance gene $\cdot$ Linkage mapping

\section{Introduction}

Barley (Hordeum vulgare L.) is the second most important cereal according to harvest area in Europe (FAOSTAT 2016. http://www.fao.org/faostat) and is generally grown as fodder and for brewing purposes. Although barley has low environmental requirements and can be farmed under harsh conditions (Nevo 1992; Stanca et al. 1992; Newton et al. 2010; Honsdorf et al. 2014), fungal infections are a cause of concern. Blumeria graminis (D.C.) Golovin ex Speer f. sp. hordei Em. Marchal (Bgh) is an obligate Ascomycota pathogen that causes powdery mildew, one of the most widespread foliar diseases. Infection by this fungus leads to yield loss and decreased feed and malting quality. The two common

Communicated by: Barbara Naganowska

Urszula Piechota

u.piechota@ihar.edu.pl

1 Plant Breeding \& Acclimatization Institute - National Research Institute, Radzików, 05-870, Błonie, Poland approaches of controlling epidemics involve the use of fungicides and the cultivation of resistant crops. Chemical protection can provide positive selection for pathogen fungicideresistant strains (Lucas et al. 2015), whereas the cultivation of resistant crop varieties is among the most economically effective and environmentally friendly methods of controlling disease.

Resistance genes for powdery mildew are widely distributed on the barley genome. Known resistance genes mapped on the barley genome include Mla - with almost 30 alleles, as well as five other genes - Mlat, MlGa, Mlk, Mlnn, and Mlraon the chromosome $1 \mathrm{H} ;$ MlLa on $2 \mathrm{H} ;$ mlo, Mlg, and MlBo on $4 \mathrm{H}$; $M l j$ on $5 \mathrm{H}$; Mlh on 6H; and mlt and Mlf on 7H (Jørgensen and Wolfe 1994; Schönfeld et al. 1996). Except for mlo, all of these genes are race-specific, major resistance genes and subject to the "boom and bust effect," with newly emerging pathotypes eventually overcoming resistance within a few years. The most effective and durable resistance depends on $m l o$, a recessive allele originating from Ethiopian landraces (Büschges et al. 1997) that has been widely introduced into European cultivars. However, the introduction of mlo can generate some negative outcomes: Mlo-resistant varieties are 
more susceptible to necrotrophic and hemibiotrophic pathogens (Brown and Rant 2013), and mlo has an impact on yield by decreasing the thousand-grain weight and yield from a given plot due to pleiotropic effects (Kjær et al. 1990).

Because of the limited number of known resistance genes utilised to control barley powdery mildew, new potential resources need to be identified. Barley landraces originate from regions with traditional and primitive farming systems, which lack explicit crop progress (Camacho Villa et al. 2005). These materials are promising sources of genetic diversity. Landraces comprise heterogenic dynamic populations subject to natural selection. Long-term co-evolution of a host with the fungus that causes powdery mildew provides low pathogen pressure and increases durability and polymorphism at resistance gene loci. Previous screening studies on powdery mildew resistance in barley landraces have revealed novel resistant lines (Comadran et al. 2009). For example, Czembor $(2000,2002)$ investigated 131 barley lines originating from Moroccan landraces. During phytopathological testing, previously unknown powdery mildew resistance genes were found in 66 lines, which showed unique resistance reaction spectra that were distinguishable from those of other known genes. Among these lines, only 255-3-3 was resistant to all 23 $B g h$ isolates studied and it exhibited no visible infection symptoms to most (74\%) of them (Czembor 2002). The aim of the present study was to identify resistance genes in barley line 255-3-3.

\section{Materials and methods}

\section{Plant materials}

Spring barley (H. vulgare) line 255-3-3 (National Centre for Plant Genetic Resources Plant Breeding and Acclimatization Institute, Poland, https://bankgenow.edu.pl, ID number 17I00361) was used for identifying powdery mildew resistance genes. This line was selected from Moroccan landrace 255 (ICARDA No. ICB 31956) and showed broadspectrum resistance to powdery mildew in a previous study (Czembor 2002).

The mapping population was derived from a cross of 2553-3 as the female parent with susceptible cv. Manchuria as the male parent.

An $F_{2}$ population derived from a cross of 255-3-3 with $\mathrm{P} 23$ (MILa) was used for allelic testing.

A set of 30 differential varieties (DV) carrying various known powdery mildew resistance genes was used for the phytopathological tests. This set contained cv. Pallas, 21 Pallas near-isogenic lines (Kølster et al. 1986) and 8 selected cultivars (Table 1). This DV set represented most of the major resistance genes used in European cultivars.
Plants were grown in a control environment under a $19^{\circ} \mathrm{C} /$ $15{ }^{\circ} \mathrm{C}$ (16-h day/8-h night) regime. For $B g h$ propagation and the phytopathological tests, the plants were grown in transparent boxes to prevent mildew contamination.

\section{Phytopathological tests}

A set of $25 B g h$ isolates collected in Poland in 2010, 2015 and 2017 were obtained from the collection of Plant Breeding and Acclimatization Institute, Poland. Bgh isolates were selected to achieve differences in virulence spectra and to specify the presence of resistance genes among the DV (Table 1).

Fungal inoculum was freshly propagated on susceptible cv. Manchuria. Ten-day-old seedlings with fully expanded first leaves were inoculated by shaking conidia from diseased plants. On the 8th day after inoculation, infection types (ITs) were scored on a 0-4-point scale (Mains and Dietz 1930), where 0,1 , and 2 indicate resistance, and 3 and 4 indicate susceptibility; extended by $0(4)$ level indicates Mlo resistance.

To determine the resistance of 255-3-3, the ITs of this line after inoculation with the set of $B g h$ isolates were compared with those obtained for the DV set. Tests were conducted with ca. 15 seedlings per line in two repetitions.

To determine the inheritance of resistance of 255-3-3, 190 $\mathrm{F}_{2}$ 255-3-3 $\times$ Manchuria plants and $128 \mathrm{~F}_{2: 3}$ families (25 individuals per family) were inoculated with the isolate $B g h 27$ avirulent to 255-3-3.

For allelic testing, $315 \mathrm{~F}_{2} 255-3-3 \times \mathrm{P} 23$ plants were inoculated with isolate $B g h 1-26$ avirulent to both parental lines.

The numbers of resistant and susceptible plants were compared to those expected based on the theoretical Mendelian segregation ratio by the chi-square $\left(\chi^{2}\right)$ test $(p=0.05)$.

\section{Molecular analysis}

Genomic DNA from 94 plants from $\mathrm{F}_{2}$ 255-3-3 × Manchuria and the parental lines was used for the molecular analysis. DNA was extracted from a single plant leaf using the CTAB method (Murray and Thompson 1980). Samples from 43 homozygous $F_{2}$ plants (22 homozygous resistant and 21 homozygous susceptible) and from the parental lines were genotyped using the DArTseq platform (Diversity Arrays Technology, Pty. Ltd.) (Von Cruz et al. 2013), and the DArTseq data were used for linkage analysis. For that purpose, DArTseq markers that were low quality, homozygous and had $>20 \%$ missing calls were removed. The remaining markers were assessed for compatibility with the resistance/ susceptibility trait. Markers with $>80 \%$ goodness of fit were evaluated by Fisher's exact test on $2 \times 2$ count tables using $R$ (www.r-project.com). The null hypothesis was a random distribution of DArTseq marker variants within resistant and susceptible plants. Significant markers according to F-test results were assigned to a genetic location by BLASTN 


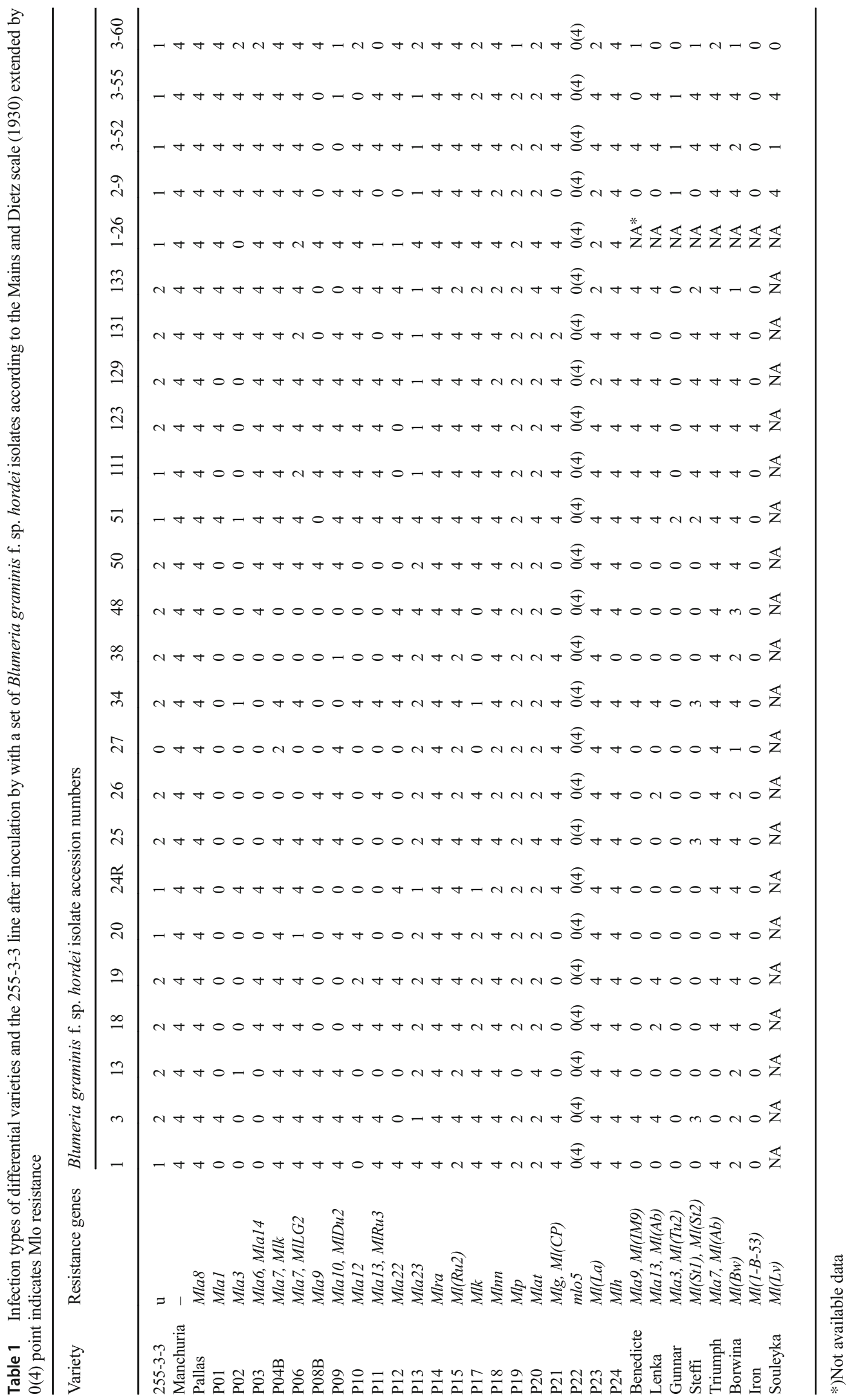


(Altschul et al. 1997) against barley genome Hv_IBSC PGSB_v2 on the EnsemblPlants database release 37 (www. plants.ensembl.org, accessed 28.11.2017) (Aken et al. 2017). Alignments with a BLASTN $E$ value $<1.0 \mathrm{E}^{-10}$ and with a minimum difference $>1.0 \mathrm{E}^{-5}$ between the first and second hits were selected for genotyping of 94 individuals from the $\mathrm{F}_{2}$ population using DArTseq markers that were converted to allele-specific dominant PCR (AS-DArT) markers. Extended DArTseq sequences from the BLASTN results were used to design allele-specific primers in BatchPrimer 3.0 (You et al. 2008 ) or manually without additional mismatch at the $-3^{\prime}$ position. The nucleotide at the $3^{\prime}$-end of the forward primer or the $5^{\prime}$-end of the reverse primer was in the SNP locus. For silicoDArT markers, allele-specific primers were designed for all six potential SNPs located in the PstI restriction enzyme recognition sequence ( $\left.5^{\prime}-\mathrm{C} \mid \mathrm{TGCAG}-3^{\prime}\right)$. The $P$ st $\mathrm{I}$ enzyme was used for the DArTseq pipeline, and the sequencing reads were consistently generated from the $P s t \mathrm{I}$ site. Other primers were designed by Primer BLAST NCBI (Ye et al. 2012). PCR products were amplified using modified DNA polymerase SNPase (GeneON GmbH, Germany) in accordance with the manufacturer's protocol. In addition, a set of 57 SSR markers was selected from the GrainGenes database (https://wheat.pw. usda.gov, access 11.2017) according to known localization on a chromosome of interest. SSRs were employed to genotype the $\mathrm{F}_{2}$ plants and parental lines. The PCR amplified fragments were separated by $1.5 \%$ agarose gel electrophoresis and visualised with ethidium bromide; fluorescently labelled fragments were detected on $4.5 \%$ polyacrylamide gels using an ABI377XL genetic analyser (Applied Biosystems, USA).

\section{Linkage analysis and genetic mapping}

Genetic linkage maps were constructed using the JoinMap 4.0 software (Stam 1993) under the standard calculation settings: linkages with a recombination frequency smaller than 0.45 and an LOD score higher than 1; goodness-of-fit jump threshold for removing loci of 3 and performing a ripple after adding 3 loci and the Kosambi mapping function (Kosambi 1944). The phenotypic scores for the $\mathrm{F}_{2}$ 255-3-3 $\times$ Manchuria population were converted to binary data according to the IT scores; specifically, 0,1 and 2 (resistant) were recoded as 1 , and 3 and 4 (susceptible) were recoded as 0 . The converted scores were included in the analysis as resistance gene RBgh255. AS-DArT, SSR markers, and the RBgh255 gene were used for genetic map construction, and another map was generated for silicoDArT markers with physical positions on $2 \mathrm{H}$. The map positions of the DArTseq markers were compared with a barley consensus $2 \mathrm{H}$ map from Barleymap database POPSEQ data (http://floresta.eead.csic.es/barleymap) (Cantalapiedra et al. 2015; Mascher et al. 2013) in MapChart software (http://www.joinmap.nl) (Voorrips 2002). Kruskal-Wallis analysis of associations between the DArTseq markers and resistance was carried out in MapQTL 6 software under standard conditions (van Ooijen 2009).

\section{Results}

\section{Phytopathological tests}

To determine the possible resistance genes present in the 2553-3 line, we assessed resistance against a diverse collection of $25 \mathrm{Bgh}$ isolates and compared the results with the ITs of the DV set carrying various resistance genes and with susceptible cultivar Manchuria as a control (Table 1). The 255-3-3 line exhibited distinctive disease response patterns, with IT scores of 0,1 , and 2 according to the Mains' and Dietz's 5-level scale (1930). The line was resistant to all $B g h$ isolates.

Evaluation of the $B g h$-inoculated $\mathrm{F}_{2} 255-3-3 \times$ Manchuria population revealed both susceptible and resistant individuals. Furthermore, phytopathological tests of $F_{2: 3}$ families showed segregating heterozygous and non-segregating homozygous $\mathrm{F}_{2}$ plants. The results of chi-squared tests confirmed the expectations of 3:1 for the $\mathrm{F}_{2}$ population and 1:2:1 for $\mathrm{F}_{2: 3}(p=$ 0.05) (Table 2).

\section{Genotyping and genetic mapping}

DArTseq analysis of 43 homozygous $\mathrm{F}_{2} 255-3-3 \times$ Manchuria plants identified 3544 codominant DArTSNP markers and 8711 dominant silicoDArT markers. Of these DArTseq markers, 33 were selected for conversion to AS-DArT markers and used to genotype $94 \mathrm{~F}_{2}$ individuals. Based on

Table 2 Segregation ratio and chi-square test results for the analysed populations after inoculation with Blumeria graminis f. sp. hordei

\begin{tabular}{|c|c|c|c|c|c|c|c|c|}
\hline \multirow[t]{2}{*}{ Population } & & \multirow[t]{2}{*}{$B g h$ isolate } & \multicolumn{3}{|c|}{ Number of plants/families } & \multirow[t]{2}{*}{ Predicted ratio } & \multirow[t]{2}{*}{$\chi^{2}$} & \multirow[t]{2}{*}{$p$ value $(p=0.05)$} \\
\hline & & & Res & Seg & Sus & & & \\
\hline \multirow[t]{2}{*}{ 255-3-3 × Manchuria } & $\mathrm{F}_{2}$ & $\operatorname{Bgh} 27$ & 145 & - & 45 & $3: 1$ & 0.1754 & 0.6753 \\
\hline & $\mathrm{F}_{2: 3}$ & $\operatorname{Bgh} 27$ & 40 & 58 & 30 & $1: 2: 1$ & 2.6875 & 0.2609 \\
\hline $255-3-3 \times$ P23 $(M l L a)$ & $\mathrm{F}_{2}$ & Bgh1-26 & 237 & - & 78 & $15: 1$ & 184.2305 & 0.0000 \\
\hline
\end{tabular}




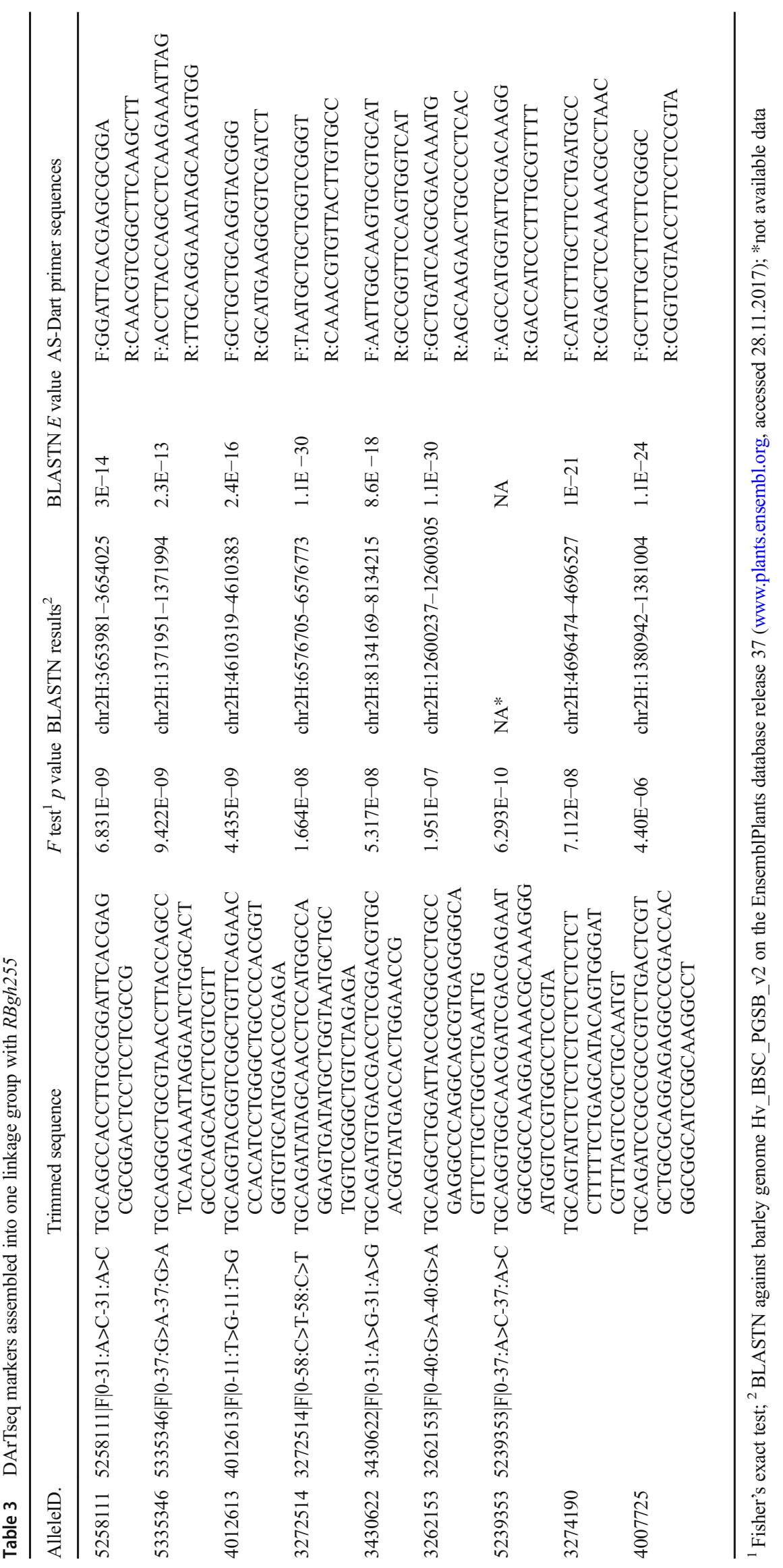


BLASTN alignment to the barley reference genome, each is located on the $2 \mathrm{H}$ chromosome.

Linkage analysis for AS-DArT (Table 3), SSR and RBgh255 assembled 14 markers into a single 36.59-cM group containing nine AS-DArTs, four SSRs, and RBgh255 (Fig. 1). Based on the known position of these markers, RBgh255 was mapped to the distal end of chromosome $2 \mathrm{H}, 5.50 \mathrm{cM}$ distal to the nearest marker 3262153.

The linkage map for the silicoDArT markers from $2 \mathrm{H}$ and RBgh255 assembled 82 markers into one linkage $10.67-\mathrm{cM}$ group (Fig. 1). RBgh255 was mapped to $3.65 \mathrm{cM}, 0.91 \mathrm{cM}$ proximal to 5249632 and 3257525 and $0.16 \mathrm{cM}$ distal to 3256284 .

The Kruskal-Wallis analysis demonstrated that only DArTseq markers mapping to the distal end of chromosome $2 \mathrm{HL}$ were significantly associated with RBgh255 (Fig. 1); the analysis did not reveal other significant loci in the genome (data not shown). The highest $K$ value $(\alpha=0.05)$ was for 3255919. The physical position of these sequences is chr2H:1839535:1839604:1 according to the barley reference genome (Table 4). These markers were previously mapped to $2.12 \mathrm{cM}$ on the $2 \mathrm{H}$ consensus barley map (Fig. 1). With reference to the highest $K$ value marker 3255919 , RBgh255 mapped $0.32 \mathrm{cM}$ distal on the silicoDArT map and $8.36 \mathrm{cM}$ distal on the AS-DArT map.

Comparative map analysis revealed eight common DArTseq markers between the AS-DArT and silicoDArT maps and 12 between the silicoDArT and consensus $2 \mathrm{H}$ maps (Fig. 1).

\section{Test of allelism}

An allelic test was performed between the barley 255-3-3 resistance gene and MlLa, a powdery mildew resistant gene previously mapped to chromosome $2 \mathrm{H}$ (Giese et al. 1993; Hoseinzadeh et al. 2019). A phytopathological test of $315 \mathrm{~F}_{2}$ 255-3-3 $\times$ P23 (MlLa) individuals revealed resistant and susceptible plants. The chi-squared test did not support a 15:1 segregating ratio (Table 2). Analysis of Res (resistant) and Sus (susceptible) AS-PCR variants of MWG097 marker linkages with MlLa (Mohler and Jahoor 1996) revealed polymorphism between the parental lines (Fig. 2). Amplification of a Sus variant was obtained for Manchuria and 255-3-3, and amplification of a Res variant was obtained for P23 (MlLa).

\section{Discussion}

Investigation of barley landrace genetic resources can broaden the available gene pool. The aim of the present study was to characterise a new source of barley resistance to powdery mildew. The barley line 255-3-3, which was previously described as having broad-spectrum resistance, originates from the Moroccan landrace (Czembor 2002). Czembor (2002)
Fig. 1 Comparative analysis of partial barley 2H maps. Comparative map analysis between the linkage map constructed for $94 \mathrm{~F}_{2}$ 255-3-3 $\times$ Manchuria plants (2H(AS-DArT)), the linkage map constructed for the silicoDArT data for 43 homozygous $\mathrm{F}_{2}$ plants $(2 \mathrm{H}($ silicoDArT) $)$ and the barley consensus genetic map (2HS(POPSEQ)); Kruskal-Wallis K-statistic plot of the associations analysis between the DArTseq markers and resistance, $\alpha=0.05$

showed that the 255-3-3 line was resistant to all $23 \mathrm{Bgh}$ isolates assessed, and exhibited an IT score of 0 according to the Mains and Dietz scale (1930) after inoculation with 17 (81\%) isolates. In the present phytopathological tests, 255-3-3 exhibited resistance to all $25 \mathrm{Bgh}$ isolates tested (Table 1). Nonetheless, due to the distinctiveness of the 255-3-3 IT spectrum from the spectra of the DV set, representing the majority of known powdery mildew resistance genes introduced into European crops (Dreiseitl 2014), the IT data did not indicate any commonly known resistance genes. This result indicates that 255-3-3 carries unique resistance genes that are not represented in the DV set.

Phenotypic analysis of $F_{2}$ and $F_{2: 3}$ progeny of 255-3-3 $\times$ Manchuria showed a segregation rate indicating a single dominant resistance gene in the 255-3-3 line.

To reveal the linkage between the resistant gene and genetic location, efforts were focused on homozygous $F_{2}$ individuals. Extreme segregants analysis on the DArTseq platform is an economical and useful method to search for significantly associated markers. DArTseq data processing allowed the construction of two linkage maps. The genetic distance of the RBgh255 resistance locus to the nearest markers is $5.5 \mathrm{cM}$ on the AS-DArT map and $0.16 \mathrm{cM}$ on the silicoDArT map (Fig. 1). As the genotyping populations comprised 94 and 43 plants, the resulting map densities are satisfactory for determining the RBgh255 locus. The results provide strong evidence for the presence of $R B g h 255$ on the distal end of chromosome $2 \mathrm{HS}$, despite divergence between the distances and the order of markers located on the analysis maps, this inconsistency was caused by the small size of the mapping population. In general, a population size ranging from 50 to 250 individuals is sufficient for preliminary genetic mapping (Mohan et al. 1997), although larger mapping populations may close the gap with markers having high linkage and producing more accurate genetic maps (Ferrera et al. 2006).

There are 13 known powdery mildew race-specific resistance genes and one partial resistance mlo gene of known position in the barley genome. Among them, only MILa has been mapped to $2 \mathrm{H}$, on the distal end of the long arm (Hoseinzadeh et al. 2019). This powdery mildew resistance gene, which originates from the botanical variety Laevigatum (Giese et al. 1993), was introduced to the Dutch cultivar 'Vada' in the 1950s. There is no known major resistance gene for powdery mildew on the short arm of chromosome $2 \mathrm{H}$ originating from cultivated barley (Jørgensen and Wolfe 1994; Schönfeld et al. 1996). 


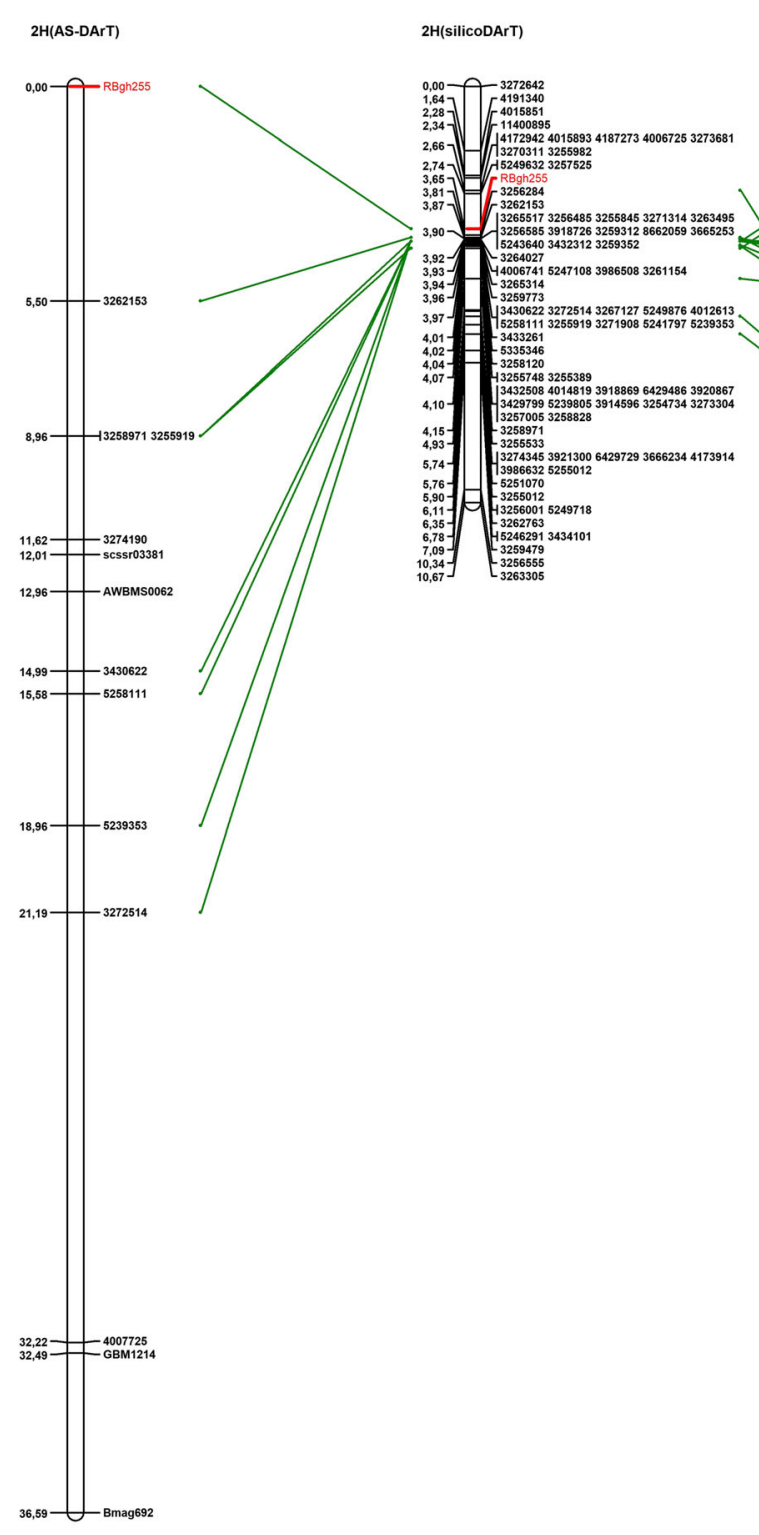

2HS(POPSEQ)

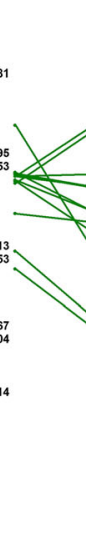

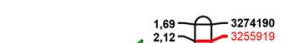

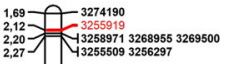

$\begin{array}{llll}3,82 & - \\ 3,92549273263719\end{array}$

\begin{tabular}{l|ll}
5,38 & & \\
5,45 & & 3269134 \\
\hline 3267574
\end{tabular}

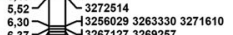

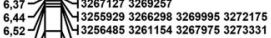

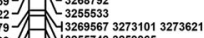

32557483259865
32567713262153

$\begin{array}{rl}32646577 \\ -3258828 & 32588813262119\end{array}$

$10.48-1325781032678013273492$

${ }_{111,61}^{11,40}-\begin{array}{r}3255812 \\ 3270104\end{array}$

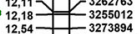

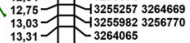
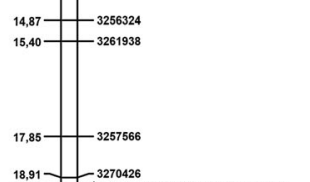

${ }_{19,05}^{18,91}{ }_{-13255272}^{327259935132616373269092}$

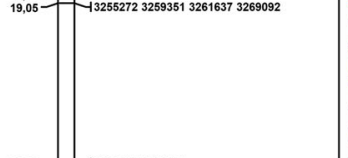

\begin{tabular}{l|l}
23.16 & -32615033261552 \\
-32553373272719
\end{tabular}

${ }_{25,35}^{25,28}{ }_{32592}^{32547}$

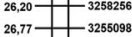

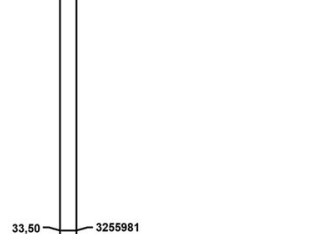

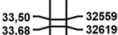

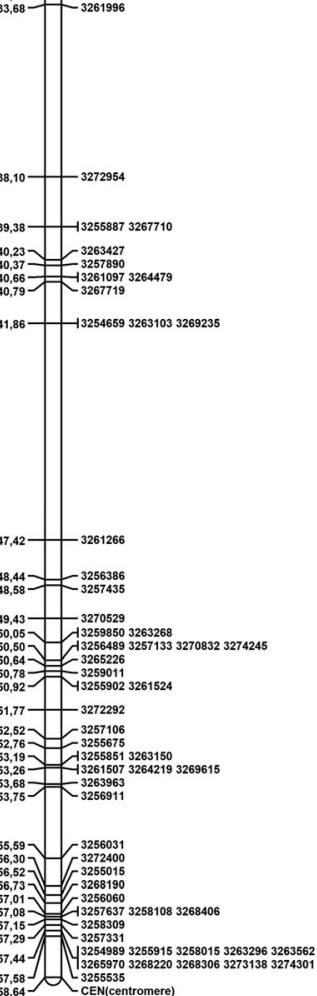

ต

-.

+.

tase

$\therefore$

$\because$

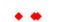

,

$\because$

.

( 


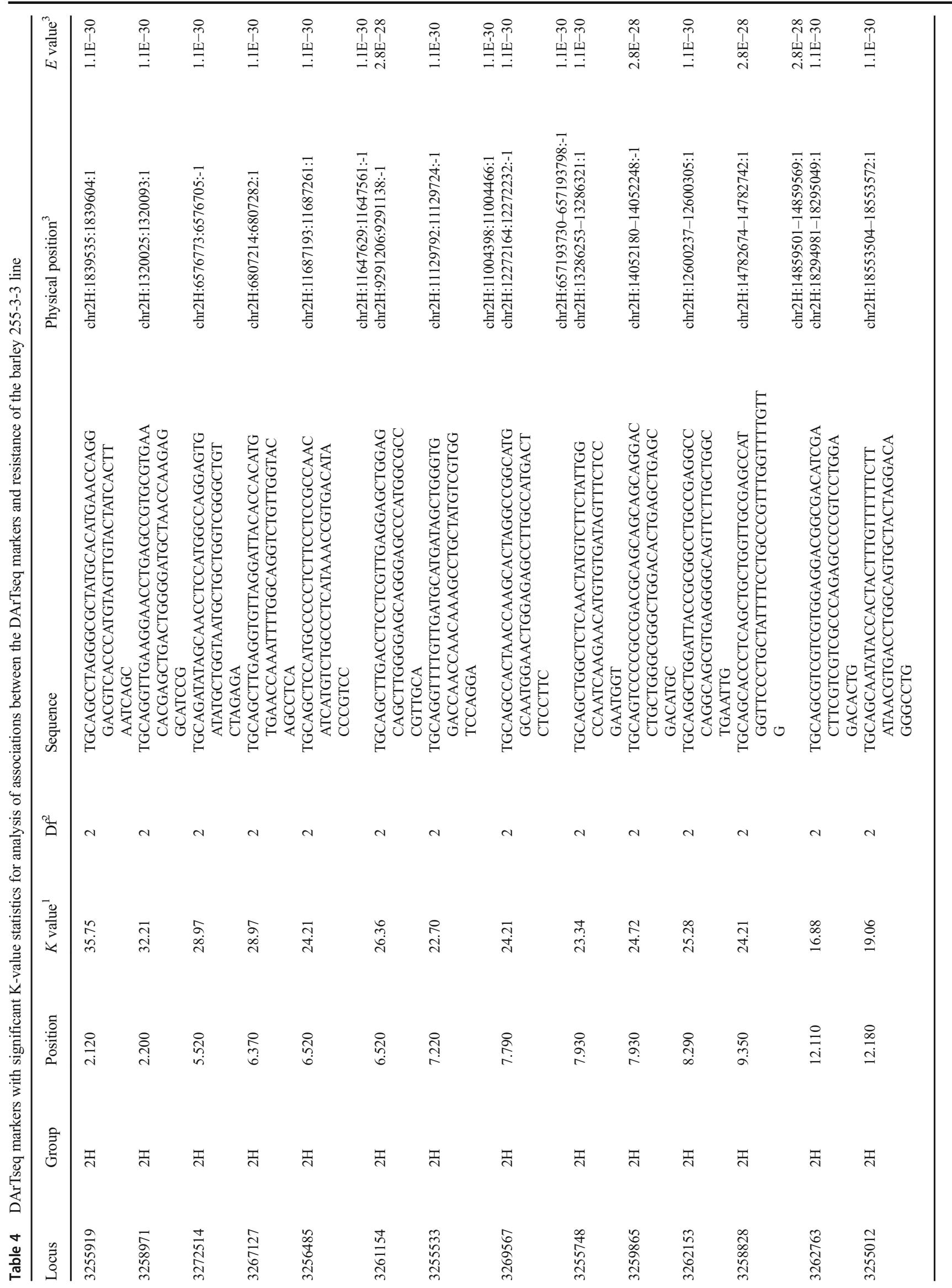




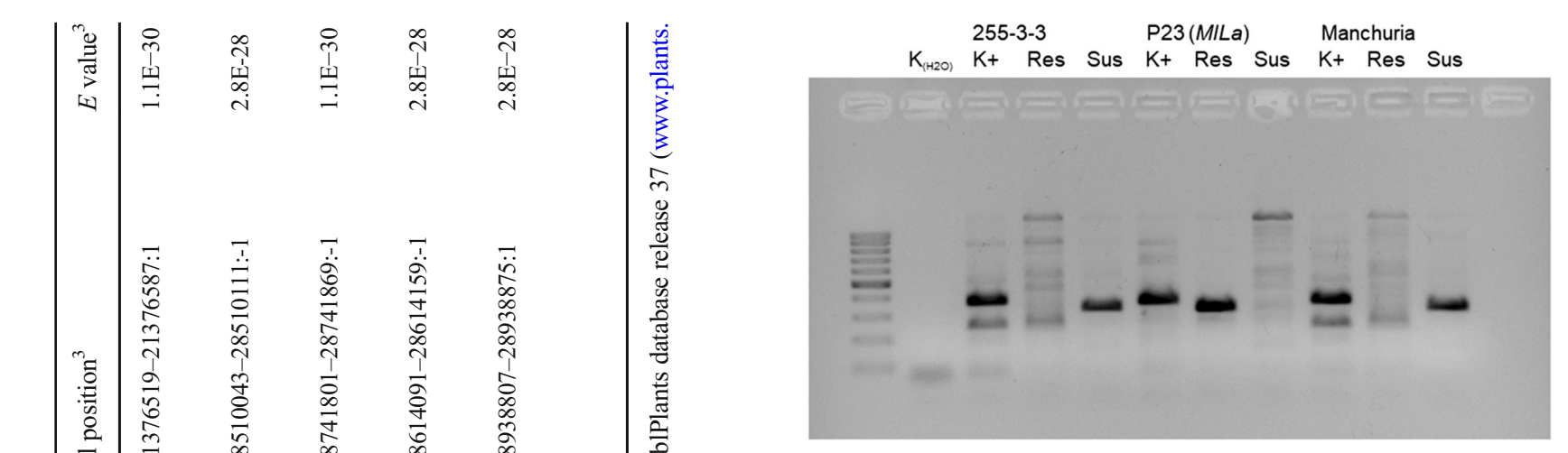

Fig. 2 Allele-specific PCR products of Res and Sus variants of marker MWG097 and original MWG097 as a positive control $(\mathrm{K}+)$; $\left(\mathrm{K}_{\mathrm{H} 2 \mathrm{O}}\right)$ not template control

An allelic test between RBgh255 and MlLa revealed segregation in the $\mathrm{F}_{2}$ generation, with susceptible individuals proving that MlLa and RBgh255 are not allelic variants. The ratio of resistant to susceptible plants within the population deviated from the expected 15:1 for two independent dominant genes, which may be due to some error in the IT rating. MlLa is known to confer moderate resistance, corresponding to scores of 2-3 on Mains' and Dietz's scale (Marcel et al. 2007), and this level of resistance may cause misclassification of resistant plants as susceptible. Res and Sus variants of the marker MWG097 (Mohler and Jahoor 1996) confirmed different variants at MlLa carried by 255-3-3 and P23 (MlLa) (Fig. 2). The different IT in interaction with the set of $B g h$ isolates utilised indicated that the resistance gene carried by 255-3-3 is not allelic to MILa (Table 1).

Extensive research on cultivars, landraces and wild barley genotypes revealed resistance loci on $2 \mathrm{H}$. $M l \mathrm{Hb}$, which is a resistance gene originating from $H$. bulbosum, was mapped to chromosome $2 \mathrm{H}(2 \mathrm{HI})$ after introgression to $H$. vulgare (Pickering et al. 1995). A strong crossing barrier between bulbous and cultivated barley excludes natural transfer of MlHb to H. vulgare (Blattner 2018). Nevertheless, Comadran et al. (2009), analysed almost 200 barley accessions from the Mediterranean basin area and indicated coincidence of the $B g h$ resistance gene with the approximate $M l H b$ location, which suggested the occurrence of an alternative resistance locus in cultivated barley located on $2 \mathrm{H}$ bins: 3,4 and 5 of the Steptoe $\times$ Morex bin map (Kleinhofs and Graner 2001; Druka et al. 2002; Cooper et al. 2004). The distal end of $2 \mathrm{H}$ bin 3 was mapped to the MWG878 marker with a physical location of approximately $11 \mathrm{Mb}$ (chr2H:1111910411119596) according to barley genome Hv_IBSC_PGSB_v2 on the EnsemblPlants database release 43 (www.plants. ensembl.org) (Aken et al. 2017). The RBgh255 resistance gene is located on $2 \mathrm{H}$ bin 1 according to the physical location of DArTseq marker 3255919 with the highest K-statistic (chr2H:1839535:1839604) (Table 4). The proximal end of $2 \mathrm{H}$ bin 1 is located on the ABG058 marker with a physical 
position of $3.2 \mathrm{Mb}$ (chr2H:3239540-3239624). Considering an approximate distance of $10 \mathrm{Mb}$ between $R B g h 255$ and the candidate genes described by Comadran et al. (2009), there is strong evidence that these loci are different. Spies et al. (2012) mapped candidate genes for resistance to $B g h$ on $2 \mathrm{H}$ in barley $\mathrm{cv}$. Steffi. This variety was included in the DV set used in this study and showed distinctive resistance spectrum from 255-33 line after inoculation with the $B g h$ set (Table 1). Genetic analysis of Steffi resistance (Spies et al. 2012) indicated quantitative trait segregation and polygenic inheritance that was opposite to the qualitative and monogenic resistance of 2553-3 line. Previous reports have also revealed Bgh resistance loci in wild barley (H. vulgare ssp. spontaneum) accessions on 2H (̌̌epková et al. 2009; Tuterová et al. 2010; Ames et al.

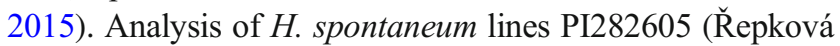
et al. 2009) and PI466197 (Tuterová et al. 2010) indicated quantitative and semi-dominant loci opposite to those of the qualitative fully dominant $R B g h 255$. Furthermore, both described QTL were mapped proximal to RBgh255, with the highest associations with Bmac0134 (chr2H:40103914010488) (Tuterová et al. 2010) and cMWG682 (chr2H:

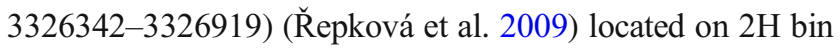
2. Since $R B g h 255$ is located on $2 \mathrm{H}$ bin 1 , this gene is very unlikely to be the same as the loci described by Řepková et al. (2009) and Tuterová et al. (2010). The powdery mildew QTL described by Ames et al. (2015) was collocated with the lang1031QPm.S42-2H.a field resistance QTL (von Korff et al. 2005) and mapped near the HVM36 marker with a physical location of $22 \mathrm{Mb}$ (chr2H:22074463-22074562) on $2 \mathrm{H}$ bin 3, which was apart from the RBgh255 resistance gene. Moreover, QTL corresponding to 2H (Aghnoum et al. 2010) are involved in seedling and adult plant resistance to $B g h$ under field and controlled conditions. Among them, Rbgq7 carries seedling resistance in controlled conditions but has been mapped on $2 \mathrm{H}$ bin 4 . These works showed many loci corresponding to $2 \mathrm{H}$ as a significant and prospective source for $B g h$ resistance. Differences in phenotypes, inheritances, and location on $2 \mathrm{H}$ between $R B g h 255$ and other described loci indicate that $R B g h 255$ is probably a distinctive and newly described resistance gene.

Resistance genes have been previously reported in landraces (Comadran et al. 2009; Czembor 2000, 2002; Newton et al. 2000; Spies et al. 2012), and have been successfully introduced into elite germplasms. These genes include $\mathrm{Mlg}$ originating from the German landrace Weihenstephan, Mla3 from the Uruguayan landrace Ricardo, Mla12 from Arabische and the durable resistance recessive gene $m l o$, originating from Ethiopian landraces. The RBgh255 gene is potentially valuable to breeders for breeding resistance to powdery mildew, and rare broad-spectrum resistance is promising for growers and interesting for scientists. According to the statement "Only when a pathogen isolate with virulence corresponding to that resistance is found can the resistance gene, according to terminology, be classified as race- specific" (Jørgensen and Wolfe 1994), a Bgh isolate virulent to 255-3-3 has not been found, in either the previous research by Czembor (2002) or this study. In this work, phytopathological tests were conducted with a Bgh set covering 21 common and known resistance genes and $13 \mathrm{Mla}$ alleles. However, a limitation of the present study is that it focused only on Polish Bgh isolates; conversely, Czembor's studies, which were conducted more than 15 years ago, utilised isolates from central Europe emerging at that time. New promising resistance genes should correspond to virulence genes in the pathogen population; therefore phytopathological tests were performed using $B g h$ collected from Poland in recent years. The study of markers linked to the identified gene provides a good basis for the development of more useful MAS markers closer to RBgh255.

This study revealed and characterised a novel powdery mildew resistance gene in barley line 255-3-3 selected from the Moroccan landrace. In accordance with nomenclature recommendations (Jørgensen 1987), the authors propose MlMor as a gene symbol for the resistance described.

Authors' contributions Piechota U. conducted experiments, analysed data, wrote manuscript; Czembor P.C. conceptualised study, reviewed manuscript; Słowacki P. isolated DNA, carried out PCRs; Czembor J.H. acquired funds, reviewed manuscript; all authors read and approved the manuscript.

Funding information The research was funded by the Ministry of Agriculture and Rural Development Poland program "Creation of scientific basis for biological improvement and plant genetic resources protection as source of innovation and support of sustainable agriculture and national food security", project no. 3200-0-02 (PW task 2.2): "Broadening of barley gene pool."

\section{Compliance with ethical standards}

Conflict of interest The authors declare that they have no conflict of interest.

Research involving human participants and/or animals The research involved neither human participants nor animals.

Informed consent Not applicable.

Open Access This article is distributed under the terms of the Creative Commons Attribution 4.0 International License (http:// creativecommons.org/licenses/by/4.0/), which permits unrestricted use, distribution, and reproduction in any medium, provided you give appropriate credit to the original author(s) and the source, provide a link to the Creative Commons license, and indicate if changes were made.

\section{References}

Aghnoum R, Marcel TC, Johrde A, Pecchioni N, Schweizer P, Niks RE (2010) Basal host resistance of barley to powdery mildew: connecting quantitative trait loci and candidate genes. Mol Plant Microbe Interact 23(1):91-102. https://doi.org/10.1094/MPMI-231-0091 
Aken BL, Achuthan P, Akanni W, Amode MR, Bernsdorff F, Bhai J et al (2017) Ensembl 2017. Nucleic Acids Res 45(D1):D635-D642. https://doi.org/10.1093/nar/gkw1104

Altschul SF, Madden TL, Schaffer AA, Zhang J, Zhang Z, Miller W, Lipman DJ (1997) Gapped BLAST and PSI-BLAST: a new generation of protein database search programs. Nucleic Acids Res 25: 3389-3402. https://doi.org/10.1093/nar/25.17.3389

Ames N, Dreiseitl A, Steffenson BJ, Muehlbauer GJ (2015) Mining wild barley for powdery mildew resistance. Plant Pathol 64:1396-1406. https://doi.org/10.1111/ppa.12384

Blattner FR (2018) Taxonomy of the genus Hordeum and barley (Hordeum vulgare). In: Stein N, Muehlbauer GJ (ed) The barley genome. Springer International Publishing AG, part of Springer Nature, Cham, Switzerland, pp 11-23. https://doi.org/10.1007/9783-319-92528-8 2

Brown JKM, Rant JC (2013) Fitness costs and trade-offs of disease resistance and their consequences for breeding arable crops. Plant Pathol 62:83-95. https://doi.org/10.1111/ppa.12163

Büschges R, Hollricher K, Pastrunga R, Simons G, Wolter M et al (1997) The barley Mlo gene: a novel control element of plant pathogen resistance. Cell 88:695-705. https://doi.org/10.1016/S00928674(00)81912-1

Camacho Villa TC, Maxted N, Scholten MA, Ford-Lloyd BV (2005) Defining and identifying crop landraces. Plant Genet Resour 3(3): 373-384. https://doi.org/10.1079/PGR200591

Cantalapiedra CP, Boudiar R, Casas AM, Igartua E, Contreras-Moreira B (2015) BARLEYMAP: physical and genetic mapping of nucleotide sequences and annotation of surrounding loci in barley. Mol Breed 35:13. https://doi.org/10.1007/s11032-015-0253-1

Comadran J, Thomas WTB, van Eeuwijk FÁ, Ceccarelli S, Grando S, Stanca AM et al (2009) Patterns of genetic diversity and linkagedisequilibrium in a high structured Hordeum vulgare associacionmapping population for the Mediterranean basin. Theor Appl Genet 119:175-187. https://doi.org/10.1007/s00122-009-1027-0

Cooper LD, Marquez-Cedillo L, Singh J, Sturbaum AK, Zhang S, Edwards V, Johnson K, Kleinhofs A, Rangel S, Carollo V, Bregitzer P, Lemaux PG, Hayeset PM (2004) Mapping ds insertions in barley using a sequence-based approach. Mol Gen Genomics 272(2):181-193. https://doi.org/10.1007/s00438-004-1035-3

Czembor JH (2000) Resistance to powdery mildew in barley landraces from Morocco. J Plant Pathol 82(3):187-200

Czembor JH (2002) Resistance to powdery mildew in selections from Moroccan barley landraces. Euphytica 125:397-409. https://doi. org/10.1023/A:1016061508160

Dreiseitl A (2014) Pathogenic divergence of central European and Australian populations of Blumeria graminis f. sp. hordei. Ann Appl Biol 165:364-372. https://doi.org/10.1111/aab.12141

Druka A, Kudrna D, Kannangara CG, von Wettstein D, Kleinhofs A (2002) Physical and genetic mapping of barley (Hordeum vulgare) germin-like cDNAs. Proc Natl Acad Sci U S A 99(2):850-855. https://doi.org/10.1073/pnas.022627999

FAOSTAT (2016) Statistical Division of the UN Food and Agriculture Organization. http://www.fao.org/faostat. Accessed May 2018.

Ferrera A, da Silva MF, Silva LDCE, Cruz CD (2006) Estimating the effects of population size and type on the accuracy of genetic maps. Genet Mol Biol 29:187-192. https://doi.org/10.1590/S141547572006000100033

Giese H, Holm-Jensen AG, Jensen HP, Jensen J (1993) Localization of the 'Laevigatum' powdery mildew resistance gene to barley chromosome 2 by the use of RFLP markers. Theor Appl Genet 85(6-7): 897-900. https://doi.org/10.1007/BF00225035

Honsdorf N, March TJ, Berger B, Tester M, Pillen K (2014) Highthroughput phenotyping to detect drought tolerance QTL in wild barley introgression lines. PLoS One 9(5):e97047. https://doi.org/ 10.1371/journal.pone.0097047
Hoseinzadeh P, Zhou R, Mascher M, Himmelbach A, Niks RE, Schweizer P, Stein N (2019) High resolution genetic and physical mapping of a major powdery mildew resistance locus in barley. Front Plant Sci 10:146. https://doi.org/10.3389/fpls.2019.00146

Jørgensen JH (1987) Specific recommendation B. Designations of barley powdery mildew resistance and virulence in Europe. In: Wolfe MS, Limpert E (ed) Integrated control of cereal mildews: monitoring the pathogen. Advances in agricultural biotechnology. Proceedings of seminar in the community programme of coordinated research of energy in agriculture, Freising-Weihenstephan, Federal Republic of Germany, 4-6 November 1986, pp 1-4.

Jørgensen JH, Wolfe M (1994) Genetics of powdery mildew resistance in barley. Crit Rev Plant Sci 13(1):97-119. https://doi.org/10.1080/ 07352689409701910

Kjær B, Jensen HP, Jensen J, Jørgensen JH (1990) Associations between three $m l$-o powdery mildew resistance genes and agronomic traits in barley. Euphytica 46:185-193. https://doi.org/10.1007/ BF00027217

Kleinhofs A, Graner A (2001) An integrated map of the barley genome. In: Phillips RL, Vasil IK (eds) DNA-based markers in plants. Advances in cellular and molecular biology of plants, vol 6 . Springer, Dordrecht

Kølster P, Munk L, Stølen O, Løhde J (1986) Near-isogenic barley lines with genes for resistance to powdery mildew. Crop Sci 26:903-907. https://doi.org/10.2135/cropsci1986.0011183X002600050014x

Kosambi DD (1944) The estimation of map distances from recombination values. Ann Eugen 12:172-175

Lucas JA, Hawkins NJ, Fraaije BA (2015) Chapter two - the evolution of fungicide resistance. Adv Appl Microbiol 90:29-92. https://doi.org/ 10.1016/bs.aambs.2014.09.001

Mains EB, Dietz SM (1930) Physiologic forms of barley mildew, Erysiphe graminis hordei Marchal. Phytopathology 20:229-239

Marcel TC, Aghnoum R, Durand J, Varshney RK, Niks RE (2007) Dissection of the barley $2 \mathrm{~L} 1.0$ region carrying the 'Laevigatum' quantitative resistance gene to leaf rust using near-isogenic lines (NIL) and subNIL. Mol Plant Microbe Interact 20(12):1604-1615. https://doi.org/10.1094/MPMI-20-12-1604

Mascher M, Muehlbauer GJ, Rokhsar DS, Chapman J, Schmutz J et al (2013) Anchoring and ordering NGS contig assemblies by population sequencing (POPSEQ). Plant J 76(4):718-727. https://doi.org/ 10.1111/tpj.12319

Mohan M, Nair S, Bhagwat A, Krishna TG, Yano M (1997) Genome mapping, molecular markers and marker-assisted selection in crop plants. Mol Breed 3:87-103. https://doi.org/10.1023/A: 1009651919792

Mohler V, Jahoor A (1996) Allele-specific amplification of polymorphic sites for the detection of powdery mildew resistance loci in cereals. Theor Appl Genet 93:1078. https://doi.org/10.1007/BF00230128

Murray AA, Thompson WF (1980) Rapid isolation of high molecular weight plant DNA. Nucleic Acids Res 8:4321-4325

Nevo E (1992) Origin, evolution, population genetics and resources for breeding of wild barley, Hordeum spontaneum, in fertile crescent. In: Shewry PR (ed) Barley: genetic, biochemistry, molecular biology and biotechnology. C.A.B. Int., Wallingford, pp 19-43

Newton AC, Guy DC, Gaunt RE, Thomas WTB (2000) The effect of powdery mildew inoculum pressure and fertilizer levels on disease tolerance in spring barley. J Plant Dis Protect 107(1):67-73. https:// www.jstor.org/stable/43215340

Newton AC, Akar T, Baresel JP, Bebeli PJ, Bettencourt E et al (2010) Cereal landraces for sustainable agriculture. Agron Sustain Dev 30(2):237-269. https://doi.org/10.1051/agro/2009032

Pickering RA, Hill AM, Michel M, Timmerman-Vaughan GM (1995) The transfer of a powdery mildew resistance gene from Hordeum bulbosum L. to barley (H. vulgare L.) chromosome 2 (2I). Theor Appl Genet 91:1288-1292. https://doi.org/10.1007/BF00220943 
Řepková J, Tuterová K, Dreiseitl A, Soldánová M (2009) Characterization and chromosomal location of powdery mildew resistance genes from wild barley PI282605. J Plant Dis Protect 116(6):257-259. https://doi.org/10.1007/BF03356319

Schönfeld M, Ragni A, Fishbeck G, Jahoor A (1996) RFLP mapping of three new loci for resistance genes to powdery mildew (Erysiphe graminis f. sp. hordei) in barley. Theor Appl Genet 93:48-56. https://doi.org/10.1007/BF00225726

Spies A, Korzun V, Bayles R, Rajaraman J, Himmelbach A, Hedley PE, Schweizer P (2012) Allele mining in barley genetic resources reveals genes of race-non-specific powdery mildew resistance. Front Plant Sci 2:113. https://doi.org/10.3389/fpls.2011.00113

Stam P (1993) Construction of integrated genetic linkage maps by means of a new computer package: JoinMap. Plant J 3(5):739-744. https:// doi.org/10.1111/j.1365-313X.1993.00739.x

Stanca AM, Terzi V, Cattivelli L (1992) Biochemical and molecular studies of stress tolerance in barley. In: Shewry PR (ed) Barley: genetic, biochemistry, molecular biology and biotechnology. C.A.B. Int., Wallingford

Tuterová K, Řepková J, Lizal P, Dreiseitl A (2010) Mapping of powdery mildew resistance gene in newly determined accession of Hordeum vulgare ssp. spontaneum. Ann Appl Biol 156(2):157-165. https:// doi.org/10.1111/j.1744-7348.2009.00375.x

Van Ooijen JW (2009) MapQTL® 6, software for the mapping of quantitive trait loci in experimental populations of diploid species. Kyazma BV, Wageningen
Von Cruz M, Kilian A, Dierig DA (2013) Development of DArT marker platforms and genetic diversity assessment of the U.S. collection of the new oilseed crop Lesquerella and related species. PLoS One 8(5):e64062. https://doi.org/10.1371/journal.pone.0064062

Von Korff M, Wang H, Léon J, Pillen K (2005) AB-QTL analysis in spring barley. I. Detection of resistance genes against powdery mildew, leaf rust and scald introgressed from wild barley. Theor Appl Genet 111(3):583-590. https://doi.org/10.1007/s00122-005-2049-x

Voorrips RE (2002) MapChart: software for the graphical presentation of linkage maps and QTLs. J Hered 93(1):77-78. https://doi.org/10. 1093/jhered/93.1.77

Ye J, Coulouris G, Zaretskaya I, Cutcutache I, Rozen S, Madden T (2012) Primer-BLAST: a tool to design target-specific primers for polymerase chain reaction. BMC Bioinformatics 13:134. https://doi.org/10. 1186/1471-2105-13-134

You FM, Huo N, Gu YQ, Luo M, Ma Y, Hane D, et al. (2008) BatchPrimer3: a high throughput web application for PCR and sequencing primer design. BMC Bioinformatics 9:253. https://doi.org/ $10.1186 / 1471-2105-9-253$

Publisher's note Springer Nature remains neutral with regard to jurisdictional claims in published maps and institutional affiliations. 